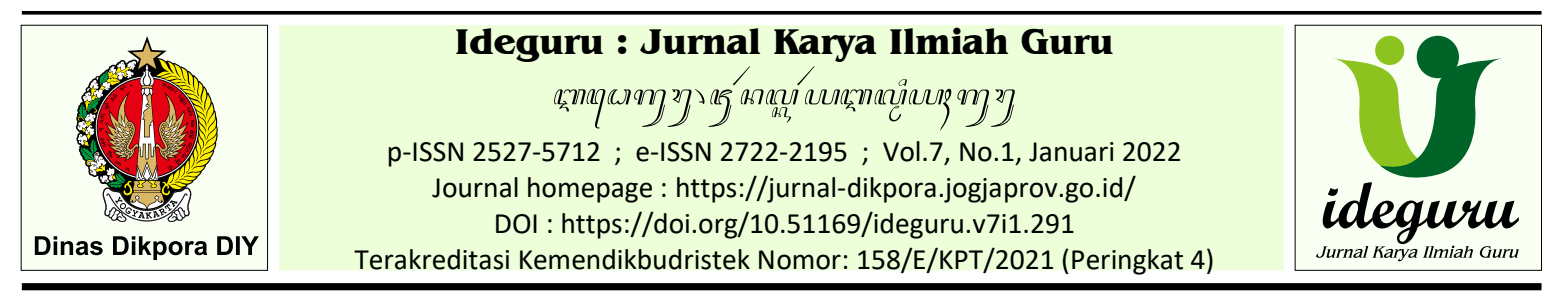

Artikel Penelitian - Naskah dikirim: 29/05/2021 - Selesai revisi: 01/12/2021 - Disetujui: 02/12/2021 - Diterbitkan: 01/01/2022

\title{
Peningkatan Motivasi Belajar Menggunakan Project Based Learning (PjBL) melalui Media Vlog Materi Senam Aerobik
}

\author{
Siti Zaeriyah \\ SMA Negeri 5 Yogyakarta, Yogyakarta, Daerah Istimewa Yogyakarta, Indonesia \\ sitizaeriyah66@gmail.com
}

\begin{abstract}
Abstrak: Pembelajaran daring saat ini dilaksanakan untuk mengatasi kesulitan proses belajar tatap muka akibat adanya pandemi COVID-19. Maka dari itu, penelitian ini bertujuan untuk menjabarkan pelaksanaan peningkatan motivasi belajar siswa menggunakan Project Based Learning (PjBL) media vlog dengan materi senam aerobik di SMA N 5 Yogyakarta. Penelitian ini dilaksanakan pada kelas XII IPS 2 berisi 32 siswa pada semester 2 tahun pelajaran 2020/2021 Penelitian ini adalah Penelitian Tindakan Kelas (PTK) yang dilaksanakan dalam dua siklus. Instrumen pengambilan data yang digunakan adalah angket motivasi, hasil observasi, hasil catatan lapangan, dan dokumentasi. Teknik analisis data yang digunakan dalam penelitian ini adalah analisis deskriptif kualitatif untuk menjelaskan hasil perhitungan angket motivasi siswa pada tiap aspek yang diamati. Hasil penelitian menunjukkan bahwa pembelajaran model Project Based Learning (PjBL) berbasis vlog dapat meningkatkan motivasi belajar materi senam aerobik untuk siswa kelas XII IPS 2 SMA Negeri 5 Yogyakarta. Pada Siklus 1 motivasi belajar siswa mencapai kategori tinggi sedangkan motivasi belajar siswa pada Siklus 2 mencapai kategori sangat tinggi. Berdasarkan indikator keberhasilan, maka disimpulkan bahwa pencapaian motivasi belajar siswa pada Siklus 1 baru sebesar 74, 75. Sedangkan pada Siklus 2 pencapaian motivasi belajar siswa sebesar 87, 25 sehingga sudah mencapai keberhasilan.
\end{abstract}

Kata kunci: Project Based Learning (PjBL); vlog; motivasi; senam aerobik.

\section{Improvement in Learning Motivation Using Project Based Learning (PjBL) through Vlogging on Aerobic Material}

\begin{abstract}
Online learning is currently applied to overcome the difficulties of the face-to-face learning process due to the COVID-19 pandemic. Therefore, this study aims to describe the implementation of increasing student learning motivation using Project Based Learning (PjBL) using vlog media with aerobic material at SMA N 5 Yogyakarta. This research was implemented in class XII IPS 2 containing 32 students in semester 2 of the 2020/2021 academic year. This research was a Classroom Action Research (CAR) which was done in two cycles. The data collection instruments used were motivation questionnaires, observation results, field notes, and documentation. The data analysis technique used in this research is descriptive qualitative analysis to explain the results of the calculation of student motivation questionnaires in each observed aspect. The results of the study is that learning the vlog-based Project Based Learning (PjBL) model can increase the motivation to learn aerobic exercise material for students of class XII IPS 2 SMA Negeri 5 Yogyakarta. In Cycle 1, students' learning motivation reached a high category, while students' learning motivation in Cycle 2 reached a very high category. Based on the indicators of success, the achievement of student learning motivation in Cycle 1 was only 74.75. While in Cycle 2 the achievement of student learning motivation was 87.25 so that it had achieved success. Therefore, it can be concluded that the study is succeed.
\end{abstract}

Keywords: Project Based Learning (PjBL); vlog; motivation; aerobics.

\section{Pendahuluan}

Dunia mengalami perubahan yang sangat drastis di awal tahun 2020. Kemunculan satu virus mematikan bernama Coronavirus Disease (COVID-19) yang diberitakan berasal dari Wuhan, China (Susilo dkk, 2020) menyebabkan tatanan dunia berubah. COVID-19 ini muncul di Indonesia pada bulan Maret 2020 dan terus bertambah hingga tercatat sebanyak 172.053 kasus terkonfirmasi positif COVID-19 per tanggal 30 Agustus 2020 (Kemenkes RI, 2020). Penyebaran yang sangat masif ini memaksa pemerintah melakukan berbagai upaya untuk menanggulanginya. Usaha pencegahan tertularnya virus ini adalah dengan menerapkan gaya hidup sehat, rajin mencuci tangan 
menggunakan sabun dan air mengalir, serta memakai masker dan menjaga jarak aman minimal 1 meter untuk melindungi dari orang batuk dan bersin. Melakukan jaga jarak ini memiliki istilah tersendiri yaitu physical distancing. Untuk menyukseskan physical distancing, maka pemerintah melakukan pembatasan terhadap aspek-aspek yang melibatkan kontak fisik, berkerumun, serta mobilitas manusia yang tinggi.

Salah satu aspek yang terdampak pembatasan tersebut adalah pendidikan. Proses belajar mengajar di sekolah dengan bertatap muka tentu melibatkan banyak orang dan berkerumun. Maka dari itu, pemerintah mengeluarkan peraturan untuk mengatasi hal tersebut. Dalam Peraturan Presiden Nomor 21 Tahun 2020 pasal 4 tertulis bahwa salah satu usaha untuk mengurangi dampak virus COVID 19 adalah dengan peliburan sekolah dan tempat kerja. Keputusan tersebut tentu memberikan dampak yang sangat besar terhadap kelangsungan pendidikan di Indonesia. Peliburan sekolah secara otomatis akan menghentikan proses belajar mengajar di sekolah sehingga siswa juga tidak akan mendapatkan materi pelajaran yang semestinya di dapatkan di sekolah. Maka dari itu, Kementrian Pendidikan mengeluarkan peraturan terbaru yaitu pelaksanaan pembelajaran pembelajaran jarak jauh atau dengan kata lain pembelajaran dalam jaringan internet (daring).

Pelaksanaan pembelajaran daring tentu saja sangat berkaitan dengan penggunaan teknologi, seperti internet, gawai pintar, dan laptop. Banyak cara yang dapat dilakukan untuk mensukseskan pembelajaran daring. Salah satu contoh media pembelajaran terkini yang dirasa mampu mengakomodasi pembelajaran praktik pada masa belajar jarak jauh seperti sekarang adalah pembelajaran berbasis vlog. Vlog sendiri merupakan kependekan dari video blogging yang artinya video dokumentasi kegiatan dari seseorang. Vlog pada umumnya berisi opini atau cerita aktivitas sehari-hari dari seorang vlogger, sebutan bagi pembuat vlog (David, dkk, 2017). Guru dapat merekam penjelasan materi pelajaran yang akan disampaikan kemudian siswa dapat melihat, mengamati, dan mendengarkan dengan lebih interaktif melalui hasil rekaman tersebut.

Mata pelajaran olahraga adalah pelajaran yang membutuhkan lebih banyak praktik di luar ruangan kelas. Siswa tidak hanya mendapatkan materi secara tertulis dalam buku acuan, namun juga harus menerima pembelajaran praktik pada gerakan-gerakan olahraga. Sukintaka (2004) menuturkan bahwa mata pelajaran pendidikan jasmani memiliki tujuan untuk mengembangkan kebugaran jasmani lewat aktivitas, perilaku hidup sehat, serta sikap sportif. Samsudin (2008) juga menambahkan bahwa materi pendidikan jasmani terdiri dari mempraktikkan ketrampilan dasar permainan dan olahraga sehingga siswa mampu memahami mengapa manusia bergerak dan bagaimana cara melakukannya dengan benar. Maka dari itu, mata pelajaran olahraga perlu diadakan pembelajaran praktik untuk menunjang teorinya.

Peneliti telah menentukan materi olahraga yang akan diajarkan menggunakan media vlog adalah materi senam aerobik. Nurmayanti (2013) dalam tulisannya menuturkan bahwa senam merupakan latihan gerak untuk seluruh anggota tubuh yang pada umumnya berurutan dimulai dari gerakan pemanasan, inti, lalu diakhiri dengan pendinginan. Senam dikelompokkan menjadi dua sifat, yakni aerobik dan anaerobik. Menurut Federation of Internasionale Gymnastic (FIG) yang dikutip oleh Atmaja (2008), senam aerobik memiliki ciri, yaitu gerakannya relatif mudah, intensitas gerakan rendah sampai sedang, durasinya relatif lama minimal 8 menit, dan dapat diikuti oleh semua kelompok umur. Maka dari itu, pemebelajaran olahraga materi senam aerobik akan mendiskusikan gerakan-gerakan senam yang benar dan menyehatkan.

Pembelajaran daring dalam pelaksanaannya terdapat banyak tantangan. Guru yang harus memahami sistem belajar melalui jaringan internet dan perkembangan gawai yang semakin maju serta siswa yang juga harus beradaptasi dengan suasana belajar yang berbeda dari umumnya. Basar (2021) dalam penelitiannya memaparkan hambatan pembelajaran daring yang dialami oleh siswa, diantaranya: (1) mudah merasa jenuh, (2) kurangnya motivasi belajar akibat tidak ada pendampingan langusng baik dari guru maupun orang tua khususnya untuk yang kedua orang tuanya bekerja, dan (3) hasil belajar kurang memuaskan akibat kesulitan memahami materi yang dipaparkan melalui media online. Surat kabar Kompas (2020) juga menuturkan bahwa Komisi Perlindungan Anak Indonesia (KPAI) mendapatkan 213 aduan kurang menyenangkan baik dari orang tua maupun siswa terhadap proses pembelajaran daring. Sardiman (2014) menyebutkan bahwa tingkat keberhasilan proses belajar pada seorang siswa bergantung pada diri sendiri dan lingkungan. Keinginan belajar dari dalam diri seseorang ini yang disebut dengan motivasi. Media belajar adalah faktor dari lingkungan. Motivasi memiliki dua peran utama yakni 1) 
sebagai penggerak untuk menghidupkan keinginan belajar dan mencapai tujuan yang diharapkan, dan 2) memberi semangat dan rasa senang selama proses belajar (Palittin, \& Purwanti, 2019). Siregar \& Nara (2011) memberikan pernyataan bahwa hasil belajar dapat dipengaruhi oleh motivasi belajar, sehingga bila motivasi belajar tinggi kemungkinan hasil belajarnya akan lebih baik. Maka, penting untuk menumbuhkan motivasi belajar yang tinggi sehingga hasil yang dikeluarkan juga meningkat. Berdasarkan fakta tersebut, maka penelitian ini bertujuan untuk mengkombinasikan pembelajaran daring dengan model pembelajaran Project Based Learning (PjBL) media vlog agar mampu meningkatkan motivasi belajar siswa pada mata pelajaran senam aerobic.

PjBL adalah model pembelajaran yang terfokus pada mengembangkan dan mengaplikasikan teori pada proyek yang dikerjakan oleh siswa (Afriani \& Fitriani, 2016). PjBL merupakan pembelajaran yang dimulai dengan mengidentifikasi masalah kemudian mengarahkan siswa untuk menemukan solusi dan menerapkannya pada produk sebagai hasil kerja proyek sehingga guru hanya bertindak sebagai fasilitator (Wena, 2010). Penerapan model $P j B L$ dalam penelitian ini adalah dengan meminta siswa mengamati rekaman $v \log$ senam aerobik yang telah dibuat oleh guru, kemudian diminta untuk mengamati video senam aerobik dari berbagai sumber hingga langkah terkahir yaitu menugaskan siswa untuk membuat sendiri gerakan senam aerobik berdasarkan video yang telah diamati.

Susanti (2019) memaparkan bahwa pemanfaatan media $v \log$ sebagai hasil dari model $P j B L$ pada mata pelajaran sejarah mampu mendorong siswa untuk lebih kreatif dan termotivasi belajar. Hal tersebut dikarenakan siswa akan terpacu untuk mencari tahu lebih dalam materi apa yang akan ditampilkan sebagai konten dalam vlog-nya. Berdasarkan hasil penelitian tersebut, maka peneliti menggunakan media $v \log$ untuk membantu proses pembelajaran praktik senam aerobik.

Febrianti (2014) memaparkan dalam tulisannya bahwa pembelajaran olahraga materi bola voli kurang diminati oleh siswa. Maka dilakukan pembelajaran menggunakan media video untuk meningkatkan minat belajar siswa terhadap materi bola voli. Penelitian tersebut mendapatkan hasil yaitu tingkat minat siswa setelah menggunakan media video lebih tinggi daripada tidak menggunakan media video.
Dari bebagai ulasan di atas, maka penulis merumuskan masalah dalam penelitian ini yaitu apakah pembelajaran model $P j B L$ dengan media vlog dapat meningkatkan moivasi belajar siswa pada materi senam aerobik. Penelitian ini bertujuan untuk mengetahui peningkatan motivasi belajar olahraga pada materi senam aerobik menggunakan model pembelajaran Project Based Learning (PjBL) dengan media vlog di SMA N 5 Yogyakarta.

\section{Metode Penelitian}

Penelitian ini dilaksanakan kelas XII IPS 2. SMA Negeri 5 Yogyakarta pada semester 2 tahun pelajaran 2020/2021. Subjek penelitian adalah siswa kelas XII IPS 2 yang berjumlah 32 orang.

Penelitian ini menggunakan metode penelitian tindakan kelas (PTK) yang dilaksanakan dalam dua siklus. Pada siklus pertama dilaksanakan pembelajaran dengan materi pemanasan dan inti I. Pada siklus kedua dilaksanakan pembelajaran dengan materi inti II dan pendinginan. Pada setiap awal siklus, guru memberikan $v \log$ yang berisi gerakan senam aerobic yang benar sesuai materi yang disampaikan.

Sumber data dalam penelitian ini diperoleh dari data angket motivasi belajar setelah pembelajaran menggunakan model Project Based Learning (PjBL) dengan media vlog serta keterlaksanaan pembelajaran yang sesuai dengan RPP. Teknik pengumpulaan data yang digunakan adalah dengan menggunakan kuesioner atau angket, oberservasi saat proses pembelajaran, catatan lapangan, wawancara, dan dokumentasi. Teknik analisis yang digunakan dalam penelitian ini adalah analisis deskriptif kualitatif karena analisis ini terpaut dengan uraian deskriptif tentang hasil dari penerapan model pembelajaran $P j B L$ media $v \log$. Sukmadinata (2011) mengemukakan bahwa analisis tersebut sesuai untuk mendeskripsikan fenomena yang terjadi saat pelaksanaan penelitian. Analisis deskriptif kualitatif ini dilaksanakan melalui observasi, wawancara, dan dokumentasi.

Daryanto (2014) memaparkan langkahlangkah pembelajaran model $P j B L$ yaitu guru menentukan pertanyaan mendasar terkait materi yang disampaikan, kemudian dilanjutkan dengan merancang perencanaan proyek. Langkah selanjutnya yaitu menyusun jadwal untuk pelaksanaan proyek. Kemudian saat kegiatan pembelajaran dilaksanakan, guru mengawasi siswa dalam menyelesaikan proyek dan kemudian diikuti dengan penilaian hasil proyek. Proses terakhir ialah mengevaluasi atau refleksi pelaksanaan proyek. Dalam penelitian ini, siswa 
diberikan teori dasar gerakan senam aerobic dasar yaitu pemanasan, inti dan pendinginan (Atmaja, 2008). Guru mencontohkan gerakan yang benar sesuai dengan teori melalui rekaman vlog sehingga siswa mendapatkan gambaran yang nyata. Langkah selanjutnya siswa diminta untuk melakukan pengamatan pada video senam aerobic bersumber dari youtube. Siswa kemudian diberikan penugasan proyek untuk membuat rekaman $v \log$ senam aerobic sesuai dengan kreativitas masing-masing setelah mengamati berbagai macam gerakan senam aerobic. Langkah yang terakhir adalah melakukan penilaian pada hasil $v \log$ siswa dan memberikan angket motivasi belajar sebagai bahan refleksi.

Angket motivasi belajar berisi pertanyaan seputar refleksi diri pada saat pembelajaran daring materi senam aerobik menggunakan model PjBL dengan media $v$ log. Terdapat 13 butir pertanyaan yang wajib diisi siswa dengan jujur. Hamzah (2011) menyebutkan bahwa untuk melihat seberapa tinggi motivasi belajar seseorang adalah menggunakan indikator sebagai berikut, 1) mempunyai keinginan untuk berhasil, 2) tumbuh dorongan dalam kebutuhan belajar, 3) memiliki cita-cita, 4) menerima penghargaan dalam belajar, 5) terdapat ketertarikan untuk mendalami materi, dan 6) berada dalam lingkungan belajar yang kondusif. Berdasarkan banyak indikator di atas, peneliti menentukan pertanyaan dalam angket motivasi belajar agar sesuai dengan teori dan dapat dengan ringkas menilai tingkat motivasi siswa, yaitu 1) Tekun menghadapi tugas, 2) Ulet menghadapi tugas, 3) Menunjukkan minat belajar, 4) Senang mengikuti pelajaran.

Proses pengolahan data kuantitatif terdapat dua tahap analisis yaitu, hasil observasi kegiatan dan perhitungan angket. Pada hasil observasi kegiatan dilakukan analisis data melalui pengisian lembar observasi dengan cara menghitung persentase skor. Pedoman penskoran untuk lembar observasi kegiatan pembelajaran adalah sebagai berikut: Skor 1, jika guru melaksanakan aspek yang diamati, dan Skor 0 , jika guru tidak melaksanakan aspek yang diamati.

Jumlah skor yang diperoleh selanjutnya dihitung besar persentasenya dengan menggunakan rumus yang dimodifikasi dari Nana Sudjana (2010: 129) berikut.

$$
P=\frac{\sum f}{f_{\max }} x 100
$$

Keterangan:

$P \quad=$ Persentase skor observasi tiap pertemuan.

$\Sigma f \quad=$ Jumlah skor yang diperoleh tiap pertemuan.

fmaks $=$ Jumlah skor maksimal yang mungkin diperoleh.

Hasil persentase tersebut kemudian dikategorikan untuk membuat kesimpulan mengenai aktifitas dalam pembelajaran penjasorkes menggunakan model pembelajaran Project Based Learning (PjBL) berdasarkan tabel 1 berikut ini.

Tabel 1. Kriteria Keterlaksanaan Kegiatan Guru

\begin{tabular}{ccc}
\hline No. & Skor & Kualifikasi \\
\hline 1. & $80<P \leq 100$ & Sangat Tinggi \\
2. & $70<P \leq 80$ & Tinggi \\
3. & $60<P \leq 70$ & Sedang \\
4. & $50<P \leq 60$ & Rendah \\
5. & $0<P \leq 50$ & Sangat Rendah \\
\hline
\end{tabular}

(Dimodifikasi dari Sugiyono, 2010)

Langkah selanjutnya adalah menghitung skor angket motivasi belajar. Rumus untuk menghitung nilai dari angket motivasi belajar adalah sebagai berikut.

$$
P=\frac{\sum f}{f_{\max }} x 100
$$

Keterangan:

$P \quad=$ Persentase skor motivasi belajar.

$\Sigma f \quad=$ Jumlah skor yang diperoleh dari angket motivasi belajar.

fmaks $=$ Jumlah skor maksimal yang mungkin diperoleh.

Nilai persantase untuk motivasi yang didapat di tafsirkan berdasarkan tabel 2 berikut.

Tabel 2. Kriteria Motivasi Belajar

\begin{tabular}{lcl}
\hline No. & \multicolumn{1}{c}{ Skor } & \multicolumn{1}{c}{ Kualifikasi } \\
\hline 1. & $80<P \leq 100$ & Sangat Tinggi \\
2. & $70<P \leq 80$ & Tinggi \\
3. & $60<P \leq 70$ & Sedang \\
4. & $50<P \leq 60$ & Rendah \\
5. & $0<P \leq 50$ & Sangat Rendah \\
\hline
\end{tabular}

\section{Hasil dan Pembahasan}

Observasi awal dilakukan sebagai pertama menentukan alur penelitian ini. Hasil observasi menunjukkan bahwa pembelajaran senam aerobik yang dilaksakan pada bulan November 2020 ternyata kurang memotivasi siswa untuk bersemangat belajar. Dari 32 siswa ketika dilakukan panggilan melalui whatsapp group, 
hanya ada 20 orang saja yang memberikan respon. Hal ini menunjukkan bahwa hanya $62,5 \%$ siswa yang termotivasi dalam proses pembelajaran, sehingga sebagiannya yaitu $37,5 \%$ siswa dalam satu kelas masih kurang dalam melaksanakan motivasi belajarnya. Berdasarkan temuan tersebut, peneliti melakukan langkah selanjutnya yakni pelaksanaan pembelajaran PjBL media vlog dimulai dengan siklus 1 yang terfokus pada gerakan pemanasan dan inti. Setelah selesai pelaksanaan pembelajaran, siswa diminta untuk mengisi angket motivasi.

Proses pembelajaran PjBL pada siklus 1 menghasilkan pengamatan keterlaksanaan proses pembelajaran dalam tabel di bawah ini.

Tabel 3. Hasil Observasi Keterlaksanaan PjBL siklus 1

\begin{tabular}{lcc}
\hline \multirow{1}{*}{ Langkah PjBL } & \multicolumn{2}{c}{$\begin{array}{c}\text { Keterlak- } \\
\text { sanaan }\end{array}$} \\
\cline { 2 - 3 } & ya & tidak \\
\hline $\begin{array}{l}\text { Menentukan pertanyaan } \\
\text { mendasar terkait materi yang } \\
\text { disampaikan. }\end{array}$ & $\mathrm{V}$ \\
$\begin{array}{l}\text { Mendesain perencanaan } \\
\text { proyek. }\end{array}$ & $\mathrm{V}$ & \\
$\begin{array}{l}\text { Menyusun jadwal untuk } \\
\text { pelaksanaan proyek. } \\
\text { Memonitor siswa dalam } \\
\text { menyelesaikan proyek. }\end{array}$ & & $\mathrm{V}$ \\
$\begin{array}{l}\text { Menguji hasil proyek. } \\
\text { Mengevaluasi atau refleksi } \\
\text { pelaksanaan proyek. }\end{array}$ & $\mathrm{V}$ & $\mathrm{V}$ \\
\hline
\end{tabular}

Berdasarkan tabel 3 tersebut, masih terdapat langkah-langkah pembelajaran $\mathrm{PjBL}$ yang terlewat belum dilaksanakan. Maka dari itu, poin-poin tersebut diperbaiki pada siklus selanjutnya.

Hasil pencapaian motivasi belajar berdasarkan angket yang paling rendah terjadi pada indikator membuat catatan atau ringkasan yaitu sebesar 52, 34. Untuk mengatasi hal tersebut guru akan memantau kegiatan ini dengan cara ringkasan/catatan setiap siswa di foto dan dikirimkan melalui WhatsApp melalui direct message. Pencapaian mengajukan pertanyaan baik kepada teman maupun kepada guru juga belum tinggi. Untuk itu guru memotivasi siswa dan memberi ruang untuk mereka melakukan pertanyaan. Siswa juga belum mencapai kategori tinggi dalam indikator mempelajari materi sebelum pelajaran. Untuk itu guru memberi beberapa pertanyaan setiap kegiatan pendahuluan pada saat kegiatan belajar mengajar.

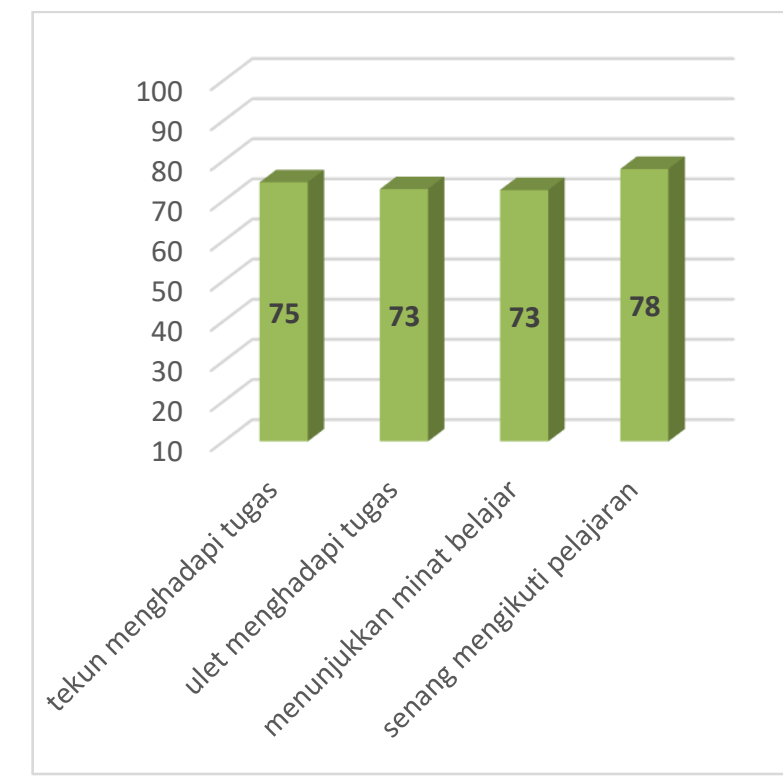

Gambar 1. Motivasi Siklus 1

Motivasi belajar siswa yang diilustrasikan pada gambar 1 di atas, pada aspek ulet menghadapi tugas dan menunjukkan minat belajar mencapai $73 \%$ sehingga masuk dalam kategori tinggi. Pada aspek tekun menghadapi tugas mencapai $75 \%$ dengan kategori tinggi. Sedangkan pencapaian motivasi belajar siswa tertinggi pada aspek senang mengikuti pelajaran yaitu sebesar $78 \%$ dengan kategori tinggi. Berdasarkan indikator keberhasilan yaitu pembelajaran dinyatakan berhasil apabila motivasi belajar mencapai 76\% maka aspek yang mencapai keberhasilan hanya pada aspek senang mengikuti pelajaran. Sedangkan pada aspek tekun menghadapi tugas, ulet menghadapi tugas dan aspek menunjukkan minat belajar belum mencapai keberhasilan.

Berdasarkan hasil tersebut, dilakukan evaluasi agar saat pelaksanaan siklus 2 hasil yang dipaparkan mengalami peningkatan. Tindakan perbaikan yang dilakukan yaitu:

Pada kegiatan pendahuluan guru menyampaikan penjelasan rencana penilaian selama pembelajaran yang akan dilakukan serta menyampaikan apersepsi dan motivasi.

Pada keterlaksanaan langkah pembelajaran menggunakan model Project based Learning guru akan menyampaikan aturan main untuk disepakati dalam proses penyelesaian proyek serta kegiatan memfasilitasi siswa untuk menyusun langkah alternatif, jika ada sub aktifitas yang molor dari waktu yang telah dijadwalkan.

Guru akan memantau kegiatan membuat ringkasan/catatan setiap siswa dengan cara mewajibkan siswa untuk mengambil gambar dengan kamera hasil ringkasan/catatan siswa 
untuk dikirim ke WhatsApp guru melalui jalur/jaringan pribadi (japri).

Untuk memberi motivasi agar semua siswa menyimak penjelasan guru maka guru akan menscreenshoot pada menu info di WhatsApp yang kemudian setelah diketahui siswa yang tidak menyimak maka guru akan menyapanya melalui direct message.

Tabel 4. Hasil Observasi Keterlaksanaan PjBL siklus 2

\begin{tabular}{lc}
\hline \multirow{2}{*}{ Langkah PjBL } & \multicolumn{2}{c}{ Keterlak- } \\
& \multicolumn{2}{c}{ sanaan } \\
\cline { 2 - 3 } ya tidak \\
\hline $\begin{array}{l}\text { Menentukan pertanyaan } \\
\text { mendasar terkait materi yang } \\
\text { disampaikan. }\end{array}$ & $\mathrm{V}$ \\
$\begin{array}{l}\text { Mendesain perencanaan } \\
\text { proyek. }\end{array}$ & $\mathrm{V}$ \\
$\begin{array}{l}\text { Menyusun jadwal untuk } \\
\text { pelaksanaan proyek. }\end{array}$ & $\mathrm{V}$ \\
$\begin{array}{l}\text { Memonitor siswa dalam } \\
\text { menyelesaikan proyek. }\end{array}$ & $\mathrm{V}$ \\
$\begin{array}{l}\text { Menguji hasil proyek. } \\
\text { Mengevaluasi atau refleksi } \\
\text { pelaksanaan proyek. }\end{array}$ & $\mathrm{V}$ \\
\hline
\end{tabular}

Berdasarkan tabel 4 terbaca bahwa secara keseluruhan pembelajaran $P j B L$ pada siklus 2 telah terlaksana sesuai dengan langkahlangkahnya. Langkah berikutnya adalah melihat hasil perhitungan dari angket motivasi siswa.

Berdasarkan gambar 2 pencapaian motivasi belajar siswa menggunakan model projectbased learning berbasis vlog pada semua aspek sudah mencapai keberhasilan karena mencapai angka lebih dari 76. dengan kategori sangat baik. Pencapaian motivasi belajar tertinggi terdapat pada aspek senang mengikuti pelajaran yaitu sebesar 90.

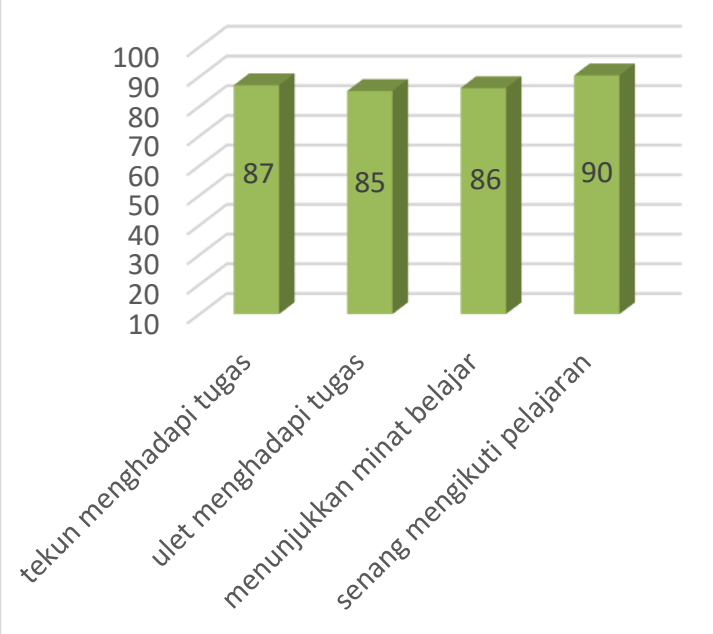

Gambar 2. Motivasi siklus 2
Dari data catatan lapangan diketahui bahwa sebagian besar siswa mengalami peningkatan semangat mengikuti pembelajaran yang dibuktikan dengan meningkatnya keterlibatan siswa secara aktif dalam mengikuti pembelajaran. Hasil proyek berupa praktik gerakan senam juga mengalami peningkatan kualitas dengan gerakan yang lebih beremangat dan dilakukan dengan senyum bahagia. Musik yang dipilih juga sudah sesuai dengan tipe gerakannya.

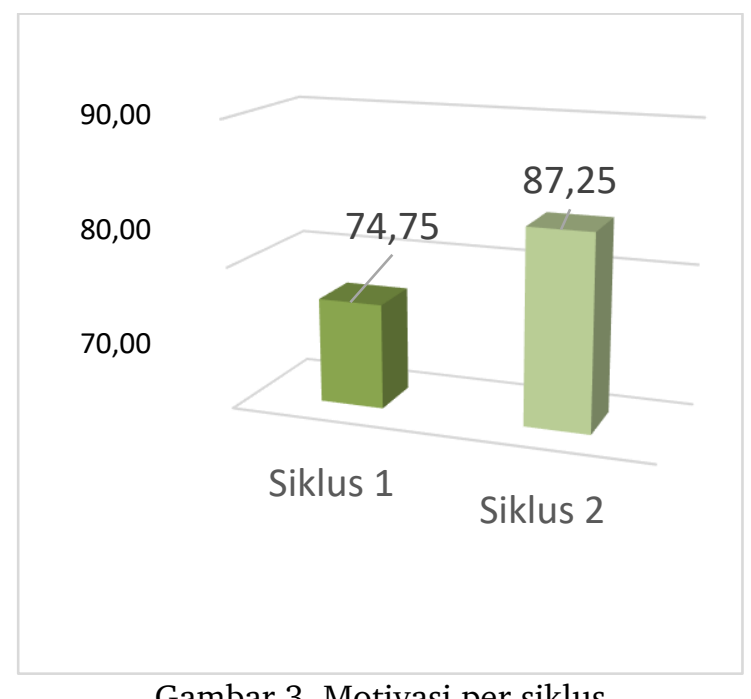

Gambar 3. Motivasi per siklus

Grafik pada gambar 3 menunjukkan motivasi belajar siswa mengalami peningkatan dari Siklus 1 ke Siklus 2. Pada Siklus 1 motivasi belajar siswa mencapai kategori tinggi sedangkan motivasi belajar siswa pada Siklus 2 mencapai kategori sangat tinggi. Peningkatan motivasi belajar siswa meliputi kenaikan pada rata-rata skor motivasi belajar siswa secara keseluruhan pada Siklus 1 dan Siklus 2, yang mencapai 12,5.

Berdasarkan indikator keberhasilan dalam penelitian ini dikatakan berhasil apabila pencapaian motivasi belajar siswa sebesar $76 \%$. Berdasarkan indikator keberhasilan tersebut maka pencapaian motivasi belajar siswa pada Siklus 1 sebesar 74, 75 sehingga belum mencapai keberhasilan. Sedangkan pada Siklus 2 pencapaian motivasi belajar siswa sebesar 87, 25 sehingga sudah mencapai keberhasilan.

Hasil penelitian ini sesuai dengan penuturan Sari (2017) dan Furi (2018) bahwa penggunaan model pembelajaran PjBL yang dikolaborasikan dengan berbagai media belajar mampu meningkatkan motivasi belajar siswa karena siswa akan terpacu untuk mengetahui bagaimana teori keilmuwan tersebut diterapkan dalam kehidupan nyata. Hasil penelitian ini juga sesuai dengan penelitian yang dipaparkan oleh Susanti (2019) yang menyatakan bahwa penggunaan media vlog mampu memotivasi belajar siswa 
karena siswa pada generasi millenial seperti saat ini sangat lekat dan familiar dengan penggunaan teknologi informatika.

\section{Simpulan dan Saran}

Berdasarkan hasil analisis di atas, dapat disimpulkan bahwa pembelajaran model Project Based Learning (PjBL) berbasis vlog dapat meningkatkan motivasi belajar pada senam aerobik siswa kelas XII IPS 2 SMA Negeri 5 Yogyakarta. Pada Siklus 1 motivasi belajar siswa baru mencapai kategori tinggi sedangkan motivasi belajar siswa pada Siklus 2 akhirnya mencapai kategori sangat tinggi. Berdasarkan indikator keberhasilan maka pencapaian motivasi belajar siswa pada Siklus 1 sebesar 74, 75 sehingga belum mencapai keberhasilan. Sedangkan pada Siklus 2 pencapaian motivasi belajar siswa sebesar 87, 25 sehingga sudah mencapai keberhasilan.

Untuk penelitian lebih lanjut, dapat dilakukan dengan media yang lain seperti pemanfaatan media sosial instagram, tiktok, dan sebagainya. Hal tersebut merujuk pada siswa generasi masa kini terbiasa menggunakan sosial di atas dalam kehidupan sehari-harinya.

\section{Daftar Pustaka}

Afriani, J. \& Fitriani, A. (2016). Penerapan Project Based Learning Terintegrasi STEM untuk Meningkatkan Literasi Sains dan Kreativitas Siswa Ditinjau Dari Gender. Jurnal Inovasi Pendidikan IPA, 2(2), 202212.

Atmaja, S. U. (2008). Kecabangan Olahraga Senam. Bandung: FPOK UPI.

Basar, A. M., (2021). Problematika Pembelajaran Jarak Jauh Pada Masa Pandemi Covid-19 (Studi Kasus di SMPIT Nurul Fajri Cikarang Barat - Bekasi). Jurnal Ilmiah Pendidikan, 2(1), 208-218.

Daryanto. (2014). Pendekatan Pembelajaran Saintifik Kurikulum 2013. Yogyakarta: Gava Media.

David, E. R., Sondakh, M., \& Harilama, S. (2017). Pengaruh Konten Vlog dalam Youtube terhadap Pembentukan Sikap Mahasiswa Ilmu Komunikasi Fakultas Ilmu Sosial dan Politik Universitas Sam Ratulangi. Jurnal Acta Diurna, 6(1). Retrieved from https://ejournal.unsrat.ac.id/index.php/act adiurnakomunikasi/article/view/15479

Furi, L M I., Handayani, \& Sri, Maharani, Shinta. (2018). Eksperimen Model Pembelajaran
Project Based Learning dan Project Based Learning Terintegrasi STEM Untuk Meningkatkan Hasil Belajar dan Kreativitas Siswa Pada Kompetensi Dasar Teknologi Pengolahan Susu. Jurnal Penelitian Pendidikan, 35(1), 49-60.

Kementerian Kesehatan Republik Indonesia. (2020). Info Infeksi Emerging Kementerian Kesehatan RI. updated 30 Maret 2020 from https://infeksiemerging.kemenkes.go.id

Kompas. (2020). KPAI Terima 213 Pengaduan Pembelajaran Jarak Jauh, Mayoritas Keluhkan Beratnya Tugas dari Guru. Retrieved from https://nasional.kompas.com/read/2020/0 4/13/15584711/kpai-terima-213pengaduan-pembelajaran-jarak-jauhmayoritas-keluhkan?page $=$ all

Palittin, I. D, Wolo, W., \& Purwanti, R. (2019). Hubungan Motivasi Belajar dengan Hasil Belajar Siswa. Magistra: Jurnal Keguruan dan Ilmu Pendidikan, 6(2), 101-109.

Peraturan Presiden Nomor 21 tentang Pembatasan Sosial Berskala Besar Dalam Rangka Percepatan Penanganan COVID-19. (2020). Jakarta

Samsudin. (2008). Pembelajaran Pendidikan Jasmani, Olahraga, dan Kesehatan. Jakarta: Prenada Media Group.

Sardiman, A. M. (2014). Interaksi dan Motivasi Belajar Mengajar. Jakarta: Rajawali Press.

Siregar, E. \& H. Nara. (2011). Teori Belajar dan Pembelajaran. Bogor: Ghalia Indonesia.

Sukintaka. (2004). Teori Pendidikan Jasmani: Filosofi, Pembelajaran, dan Masa Depan. Bandung: Penerbit Nuansa.

Sukmadinata, N. S. (2011). Metode Penelitian Pendidikan. Bandung: PT Remaja Rosdakarya.

Susanti, E. D. (2019). Project Based Learning: Pemanfaatan Vlog Dalam Pembelajaran Sejarah Untuk Generasi Pro Gadget. Jurnal Sejarah, Budaya, dan Pengajarannya, 13(1), 85-96.

Susilo, A., Rumende, C.M., Pitoyo, C.W., Santoso, W.D., Yulianti, M. (2020). Coronavirus Disease 2019: Tinjauan Literatur Terkini. Jurnal Penyakit Dalam Indonesia, 7(1), 4567.

Wena, M. (2010). Strategi Pembelajaran Inovatif Kontemporer (Suatu Tinjauan Konseptual Operasional). Jakarta: Bumi Aksara. 